ELORE (ISSN 1456-3010), vol. $18-2 / 2011$.

Julkaisija: Suomen Kansantietouden Tutkijain Seura ry.

[http://www.elore.fi/arkisto/2_11/eklund.pdf]

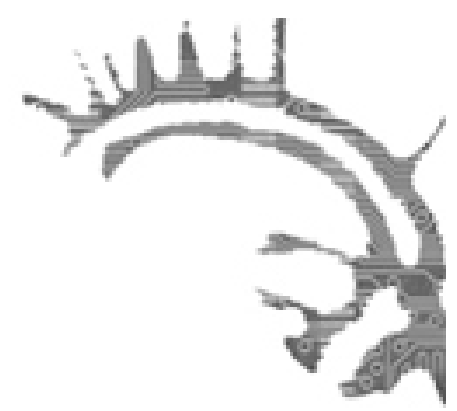

\title{
BOKRECENSION
}

\section{VöRÅFOTOGRAFEN ERIK HÄgGLUND}

HELLMAN, KATJA \& SAHLSTRÖM, META \& WEST, MONICA (red.) 2010: Blickfång. En tidsresa med Vöråfotografen Erik Hägglund. Helsingfors: Svenska litteratursällskapet i Finland. 287 sidor.

\section{Lena Marander-Eklund}

När man tar boken Blickefäng i sin hand har man en känsla av att det är fråga om en så kallad coffee table book, ett verk med vackra fotografier från ett lantligt Österbotten tagna under 1910- och 1960-talen. Vid en närmare granskning av verket gestaltas en presentation av en kulturgärning, dels en dokumentation av en mångsidig fotografs yrkesliv, dels en sammanställning av fotografier över ett folkliv i det svenskspråkiga Österbotten. Boken presenterar fotografen Erik Hägglunds fotosamling som donerades till Svenska litteratursällskapet redan år 1972. Samlingen består av cirka 40000 glasnegativ. Dessa fotografier görs nu bekanta för allmänheten genom utgivningen av denna vackert ombrutna bok. Redaktörerna för verket är etnologer verksamma vid Österbottens traditionsarkiv i Vasa.

Etnologer och folklorister har allt mera börjat intressera sig för fotografier som forskningsmaterial och också problematiserat påståenden om vad det innebär att en bild berättar mer än tusen ord, eftersom det visuella inte berättar en entydig historia utan mening ges av människor. Fotografiets förställda objektivitet har ifrågasatts samtidigt som det finns ett behov av illusionen om fotografiets verklighetsnära uttryck. Att lyfta fram etnografiskt orienterade fotografer i bokformat har blivit relativt vanligt i dag. Ett exempel på ett sådant verk är Heikki Aho och Björn Soldans Kaupunkilaiselämää - stadsliv - city life (2011). På så sätt ligger det i tiden att ge ut en praktutgåva med utgångspunkt $\mathrm{i}$ en fotografs verksamhet. 
Lena Marander-Eklund: Vöråfotografen Erik Hägglund

\section{EN RESA I TIDEN}

Fotografen Erik Hägglund föddes 1884 och levde fram till sin död 1962 i Vörå i svenska Österbotten. Han grundade sin första fotoateljé redan år 1910 och var verksam fotograf fram till sin död 1962. Redaktörerna önskar lyfta fram Hägglund dels som ett sätt att berätta om en fotografs livsverk, dels som ett sätt att presentera såväl ett landskap som befolkningens livsvillkor i förändring. Hägglunds yrkesverksamma liv presenteras i en artikel av Meta Sahlström i vilken hon skriver om hur det kom sig att han blev fotograf, hans yrkesverksamhet och hans kundkrets. Hon problematiserar också på vilket sätt Hägglund kan klassificeras som fotograf och menar att hans verksamhet passar in i den typologi som Hannu Sinisalo har utvecklat. Han var således både amatörfotograf, bygdefotograf, kringresande fotograf och ateljéfotograf. Han livnärde sig också som möbelmålare. Katja Hellman skriver om fotografier som forskningsmaterial. Här presenteras fotograferingen som en central dokumenteringsmetod inom folklivsforskningen under tidigt 1900-tal. Hon reflekterar också över förebilder för hur människor poserade när de kom till fotoateljén för att förevigas på bild. Bland Hägglunds fotografier finner man tillrättalagda ateljéfotografier, människor som är uppklädda och festliga. Men Hellman påpekar också att han förevigade det vardagliga eftersom han bland annat fotograferade arbetsmiljöer och hemmiljöer. Eftersom hans verksamhet överspänner en lång tid kan man se en förändring $\mathrm{i}$ hur människor levde och arbetade men också i vad som ansågs viktigt att fotografera. Att fotografera avlinda anhöriga uppges som ett exempel på en sedvänja som försvunnit. Förändringsperspektivet gör att boken kan ses som en resa $\mathrm{i}$ tiden.

\section{EN RESA I BILDER}

Boken är inte bara en resa i tiden, utan samtidigt också en resa i bilder till Vörå i svenska Österbotten. Den största delen av boken består av en tematisk och kronologisk framställning av Erik Hägglunds fotografier. De tematiska avsnitten följs av kommenterande text och bildtexter. I avsnittet "Bygd och miljö" presenteras ett lantligt Vörå med pörttak, odlingsmarker och gärdesgårdar och i senare tid egnahemshus. I delen som behandlar handel återfinns porträtt på så kallade laukkuryssar (också kallade "påsaryssar"), interiörbilder från apoteket och tygaffären, men också centrum på 1950-talet med butik och bensinstation. Vardagen på gården presenteras genom fotografier av kvinnor som diskar, klipper ull, väver och kardar medan männens kör gödsel, för tjurar till slaktning och gräver diken. I avsnittet om yrkeslivet presenteras bilder av postfröknar, postiljoner, skomakare, sömmerskor, smeder och minkfarmare. Fotografierna presenterar människorna i sin arbetsmiljö. I vissa fall poserar de för fotografen medan de $i$ andra fall är avbildade mitt $i$ sina sysslor. Boningshusen presenteras som ett återkommande motiv hos bygdefotograferna. Här är det både exteriörer och interiörer som förevisas. 
I temat livets gång presenteras dop, konfirmation och begravning. Men de flesta fotografierna som förevisas är från bröllop, så kallade traditionella österbottniska bondbröllop. De ateljéfotografier som valts bildar en fin framställning om hur brudens klädsel förändrats från svart klänning utan slöja på 1910-talet till vit lång klänning med tyllslöja på 1940-talet. Även bilder som presenterar livets fester presenteras. Ateljéfotografierna dominerar i avdelningen med titeln "Klädedräkt och mode". Kvinnor i skiddräkter, varav en klädd i byxor (jfr Arja Turunens avhandling [2011] om när kvinnor började bära byxor i Finland), samt rökande kvinnor i hattar gestaltar andra typer av kvinnligheter än bondkvinnan som bär huckle. Olika typer av transportmedel presenteras - allt från häst och kärra, skidor, cyklar och mopeder till bilar och bussar. En bild som visar upp en stor mängd trälådor på en åker representerar de evakuerade karelarnas ankomst till Vörå sommaren 1944. Bilden från kön till skärmbildsundersökningen demonstrerar närvaron av och bekämpningen av tuberkulos. Lottor och militärer i gruppbilder tyder på andra typer av kristid. Avdelningen "Lära för livet" gestaltar skola och utbildning i olika former men dock inte i form av traditionella klassfotografier. Kultur och föreningslivet i form av bilder från dansorkestrar, folkdansstämmor, ungdomsföreningens teaterförställning, syföreningsmöten, nykterhetsföreningen och idrottsklubben presenteras under rubriken "Nytta och nöje". Boken avslutas med en avdelning med titeln "Minnesvärt". Här återfinns Fattigubben utanför Vörå kyrka, platser och byggnader av betydelse. Intressant är att återse bilden av kopperskan Anna-Maria Kronqvist, ett fotografi som ofta får exemplifiera folkmedicinen och dess utövare. Redaktörerna för en diskussion om vem upphovsmannen till denna bild egentligen är eftersom den förekommer i tryck med varierande källhänvisningar. En förklaring till detta är, enligt Erik Hägglunds söner, att fadern ofta sålde negativen till beställaren.

Verket avslutas med en kort reflektion över arkiveringen av negativsamlingen. För att kunna identifiera personerna på bilderna har Österbottens traditionsarkiv alltsedan 1973 arrangerat tillfällen där lokalbefolkningen ombetts hjälpa till med detta. Delar av samlingen är digitaliserad och största delen registrerad. En stor samling och ett stort arbete med samlingen har nått en vändpunkt $\mathrm{i}$ och med utgivningen av boken Blickfäng. De personer som arbetat med denna otroligt omfattande och unika samling är att gratulera.

Det intressanta med verket Blickfäng är att det presenterar en fotograf som både var ateljéfotograf och etnografiskt orienterad bygdefotograf. Trots att en del av fotografierna känns relativt tillrättalagda inger de en känsla av närhet till människorna och deras liv i Vörå under första delen av 1900-talet. Bildvalet känns både välgenomtänkt och välavvägt, så även de avdelningar som boken består av. Eventuellt kunde olika perspektiv såsom kön, klass, ålder, etnicitet kommit fram tydligare, eftersom läsaren får en bild av ifrågavarande lokalsamhälle som om det vore demokratiskt med lika möjligheter för alla. Personligen anser jag att de kapitel där människor utgör bildernas fokus är de intressantaste. 


\section{LITTERATUR}

AHO, HEIKKI \& SOLDAN, BJÖRN 2011. Kaupunkilaiselämää - stadsliv - city life. Näkymiä 1930-luvun Helsinkiin. Helsinki: WSOY.

TURUNEN, ARJA 2011. Hame, housut, hamehousut! Vai mikë on tulevaisuntemme? Kansatieteellinen arkisto 53. Vaasa: Suomen muinaismuistoyhdistys.

Docent Lena Marander-Eklund är akademilektor i folkloristik vid Åbo Akademi. 